\title{
ФОРМИРОВАНИЕ И РАЗВИТИЕ ТЕОРИИ ГОСУДАРСТВЕННОГО СУВЕРЕНИТЕТА В ТРУДАХ НЕМЕЦКИХ УЧЕНЫХ XVII-XIX ВВ.
}

\begin{abstract}
Аннотация: Прочессы развития государства, как основного субъекта международного публичного права, неразрывно связано с эволюиией теории суверенитета.В настоящей статье, на основе анализа научных трудов немецких ученых XVII-ХIX вв., исследуются основные положения теории суверенитета, в соотношении с учением о государстве.Авторы прослеживают взаимосвязь типов государств, в частности, их классификаиию с формами ограничения суверенитета. Относительно теории суверенитета государства, авторы отмечают, что суверенитет как один из признаков государства, изменчив по форме, поскольку связан с правоспособностью государства. Но поскольку, согласно общей теории права, можно разделить лишь права, а не правоспособность, очевидной становится идея неделимости суверенитета. Таким образом, в зависимости от целей государства при осуществлении внутренней и внешней политики, происходит изменение видов суверенитета, сам же он остаётся неотъемлемым признаком государства. В практике международных отношений дисбаланс между его юридической и политической составляющими нередко зависит от внутренних факторов и внешних воздействий других субъектов международного права.

Review: The processes of development of the state as a main subject of international public law is inseparably connected to the evolution of sovereignty theory. This article studies the key provisions of the sovereignty theory in accordance with the teachings on state based upon analysis of the scientific works of German scientists of XVII-XIX centuries. The authors follow the connection between the types of state and their classification and the forms of limitations to sovereignty. As for the theory of state sovereignty, the authors note that sovereignty as one of the characteristic features of the state is variable in its form, since it is connected with the legal capacity of the state. But since under the general theory of law only the rights may be divided, and not the legal capacity itself, the idea of invisible sovereignty becomes obvious. Therefore, depending on the goals of the state in the spheres of its domestic and foreign policy, the types of sovereignty change, and the sovereignty itself remains an inalienable characteristic feature of a state. From the practical standpoint the lack of balance between legal and political elements of sovereignty in the foreign relations often depends on inner factors and outer influences from the other subjects of international law. Ключевые слова: Германия, власть, государство, естественное право, суверенитет, концепиия международного права, протекторат, сервитут, кондоминиум, юридический позитивизм
\end{abstract}

Keywords: Germany, power, state, natural law, sovereignty, concept of international law, protectorate, right of way, condominium, legal positivism

уверенитет государства - один из его признаков. Основным его элементом является территориальное верховенство (территориальный суверенитет), т.е. верховенство власти государства на всей государственной территории ${ }^{1}$.

Научное понятие «суверенитет» появилось в политической и международно-правовой практике в период становления абсолютных монархий и использовалось

\footnotetext{
${ }^{1}$ См.: Барсегов Ю.Г. Территория в международном праве. М., 1958. - С. 26; Вылегжанин А.Н. Подземный предел распространения суверенитета государства / Государство и право, 2001, № 8. - С. 68-74.
}

королевской властью в борьбе против феодальной раздробленности. Первоначальным носителем суверенитета считался монарх, поскольку его личность отождествлялась с личностью государства (согласно известной формуле Людовика XIV - «Государство - это я!»). И лишь с ликвидацией феодализма, государство стало рассматриваться как носитель суверенитета.

Автором теории суверенитета по праву считается Жанн Боден (1530-1596), состоявший на службе у короля Франции Генриха III в должности прокурора. Поддерживая своего короля в полемике с императором Священной Римской империи и папой, он первый пред- 
DOI: $10.7256 / 1811-9018.2013 .8 .9128$

При цитировании этой статьи сноска на doi обязательна

Правовая и политическая мысль

ложил научное понятие «суверенитет» основу которого составила новая теория о происхождении государства. После многократных изменений Ж. Боден придал современную форму учения о суверенитете и в 1576 г. изложил её в своём главном труде «Шесть книг о республике». Автор отверг теорию о божественном происхождении государственной власти и отстаивал идею наследственной монархии. Положения его учения совершенно не соответствовали представлениям других народов Западной Европы, которые основывались на идее единства всех христианских государств (res publica Christiana) с их сложной системой светских и религиозных отношений между императором Священной Римской империи и папой.

В период с XVI-XVII в.в., ведение войн было характерной особенностью для европейского континента, поэтому идеями о суверенном равенстве государств часто пренебрегали, поскольку самым убедительным аргументом оставалось право силы.

Однако, это не означало забвение учения Ж. Бодена. Сильное влияние на развитие теории суверенитета и создание системы международного права, особенно на первом этапе его развития, оказали труды учёных естественно-правового направления. Представителями которго в Германии были С. Пуфендорф, Х. Томазий, Х. Вольф, Э. де Ваттель. Их гуманистические устремления, сравнимые с философским утопизмом ${ }^{2}$ не соответствовали ценностям политиков и идеалам буржуазии ${ }^{3}$.Но, тем не менее, доктрины христианских философов составили основу международного права, которое часто называли «профессорским правом» и способствовали формированию международного правосознания.

Философско-правовые идеи немецких учёных в отношении теории суверенитета исторически развивались по двум направлениям. Представители школы естественного права С. Пуфендорф, Х. Вольф, Г. Лейбниц и С. Рахель, совершенствовали взгляды Г. Гроция. Согласно учению С. Пуфендорфа - международное право это результат разума и имеет приоритет перед национальным правом, a, следовательно, суверенитет зависит не от воли одного государства, а от общей воли нескольких государств. Х. Вольф полагал, что войны ведутся только тогда, когда кто-либо из субъектов международного права обладает абсолютной властью, значит суверенитет не признак государства, а собирательное понятие, характеризующее его

\footnotetext{
2 Лукашук И.И. Международное право: наука и практика // Межд. публ. и частное право № 2 (11), 2003. - С. 3.

${ }^{3}$ По этому поводу И. Кант критически замечал, что Г. Гроций, С. Пуфендорф, Э. де Ваттель и многие другие создали «философский и дипломатический кодекс», который «не имеет, да и не может иметь ни малейшей юридической силы». Кант И. К вечному миру // Трактаты о вечном мире. М., 2003. - С. 213, 214.
}

определённое состояние. Аналогичную точку зрения высказывал Г. Лейбниц, который рассматривал суверенитет не как признак государства, а как определённую форму его состояния. Свою позицию о теории суверенитета обосновывал тем, что абсолютной независимости государства не существует. И если в мирное время вышестоящая государственная инстанция не подчиняется нижестоящей, то в случае войны, этот элемент государства как системы - пропадает. Государство переходит в другое состояние и ни одна высшая инстанция государственной власти не сможет при помощи права устранить его ${ }^{4}$ Р. Цойх исходил из того, что позитивное право - вторичный источник международного права, а суверенитет - определённая компетенция государства. С. Рахель, разделяя его взгляды и развивая их, отмечал: «Суверенное государство характеризуется тем, что его законодательство не зависит от законодательства других стран» ${ }^{5}$.

Новое направление теории суверенитета было связано с доктриной о естественных правах человека, основные идеи которого содержались в нормах ius gentium и были заимствованы теорией государственного права. Особое развитие они получили в трудах немецкого учёного С. Пуфендорфа, прежде всего в учении о том, что долг государя - признавать человеческое достоинство его подданных. Учение С. Пуфендорфа, в системном изложении профессора М. Криле, представляло собой аргументированный анализ следующих положений:

а) идея достоинства человека базировалась отныне не на его принадлежности к тому или иному сословию и не на его заслугах, а на том, что он - человек. И если уважение этого достоинства - долг, то, следовательно, все люди заслуживают равного уважения.

б) к достоинству человека принадлежит то, что он в рамках своих обязанностей и в зависимости от внешних обстоятельств получает возможность для свободного самоопределения, позволяющего ему наилучшим образом развивать свои индивидуальные способности. Долг государя - уважать достоинство подданных - означал в XVIII в. прежде всего новое требование, а именно: уважать их убеждения и проявлять терпимость к их религиозной принадлежности. И сверх того: соблюдать действующие правовые стандарты, в особенности же не допускать произвольных арестов и преследований.

в) достоинство человека сделало необходимым признание его правового положения: из объекта обязанностей монарха человек становится субъектом права ${ }^{6}$.

\footnotetext{
${ }^{4}$ Verdross A. Die Einheit des rechtlichen Weltbildes auf Grundlage der Völkerrechtsverfassung. Vrlg. Von J.C.B. Mohr (Paul Siebel) in Tübingen. 1923. - S. 25-26.

${ }^{5}$ Verdross A. Op. cit. -27 f.f.

${ }^{6}$ Криле М. Права человека и разделение властей. // Политическая философия в Германии. Сборник статей. М., 2005. - С. 23.
} 


\section{Право и политика $8(164) \cdot 2013$}

Так возникло правовое учение, в котором обязанностям государей соответствовали наконец-то права человека: право на равенство, свободу и самоопределение. Логическим завершением этого правового учения были теория разделения государственной власти и демократия.

Основатель немецкой школы юридического позитивизма Я. Мозер, исследовавший теорию суверенитета, различал его двойственную природу. С одной стороны, суверенитет это компетенция государства. Он обостряет проблему целью суверенитета, которая состоит в установлении определённого права. Право государства есть субъективное выражение объекта его компетенции. Как последователь Г.В.Ф. Гегеля, придерживался традиционной для того исторического периода точки зрения - оправдывал войну в целях восстановления нарушенных прав. С другой стороны, суверенное государство не зависит от другого государства лишь во всемирном масштабе, т.к. в Римской католической церкви всё подчинено папе.

Несмотря на множество подходов к теории суверенитета и различие их особенностей, нередко имеющих противоречивый характер, к окончанию ХІХ-началу XX в.в. в науке сложилось общее представление о суверенном государстве. Относительное спокойствие, установившееся в научных кругах было нарушено идеями профессора Гейдельбергского университета Г. Еллинека, изложенными им в работе «Общее учение о государстве», изданной в Берлине в 1900 г. Изучая международно-правовые проблемы, он предложил теорию самоограничения государства, системно исследовал субъективные права и выступал против их нарушения. Впервые была научно обоснована плюралистическая теория государства с концепцией «несуверенного государства» и отрицания международного права. Г. Еллинек утверждал, если обязательным признаком государства выступает властная система государственных органов (армия, полиция, суды, фискальные службы и др.), то суверенитет может быть необязательным признаком государства7.

В общей теории права современного общества различают следующие виды суверенитета: территориальный, государственный и суверенитет народа. При этом следует учитывать, что каждый из обозначенных видов объективно связан (в той или иной степени) как с тремя элементами государства, так и с субъектами международного права.

Относительно формально-юридических свойств государственной территории немецкие учёные выделяют два аспекта:

\footnotetext{
${ }^{7}$ Jellinek G. Allgemeine Staatslehre. Vrlg. von O. Häring. Berlin. 1900. S. - 293-355 ff. Предложенная концепция не нашла своего отражения в юридической науке, поскольку содержание понятия «суверенитет» выражено в верховенстве государственной власти как в пределах территории государства, так и её независимости во внешних сношениях с другими субъектами международного права.
}

- право на осуществление властных полномочий в пределах государственных границ может быть получено только с разрешения высших органов государства;

- все находящиеся в пределах государственной территории категории населения (кроме лиц, обладающих дипломатическим иммунитетом) и имущество, попадают под юрисдикцию государства ${ }^{8}$.

Исследуя государство как основной субъект международного права с позиции «учения о трёх элементах», немецкие ученые XVII-XIX вв. анализировали соотношение научного понятия «территориальный суверенитет» и формы его ограничения: протекторат, кондоминиум, сервитут, территория под опекой, нейтралитет.

Протекторат характеризуется установлением на основе международного договора между сильным и слабым государством правоотношений зависимости. Покровительствуемое государство, население которого, сохраняя гражданство и обладая формально государственным суверенитетом, ограничено в свободе действий при заключении международных договоров. Государствопротекторат обязывается защищать территорию протежируемого государства и осуществлять его полномочия во внешних сношениях 9 .

Исторически протекторат устанавливался на неравноправной основе, как правило, принятием одностороннего акта ${ }^{10}$.

В практике международных отношений XIX в. великие державы устанавливали протекторат над «полуцивилизованными» странами, где население лишалось гражданских прав. Политика «защиты чужих интере-

8 Ipsen K. Völkerrecht. 5., v. neubearb. Aufl., Vrlg. C.H. Beck. München, 2004. - S. 310; 311.

${ }^{9}$ Первые признаки этого правового института просматриваются в раннефеодальном ленном праве (протекторат Испании над Монако, установленный в 1524 г., возник именно из ленных отношений Римской империи и получил широкое развитие в период колониальных войн).

В настоящее время в отношениях «покровительствуемое государство и государство-протектор» состоят Лихтенштейн и Швейцария, Сан-Марино и Италия, Монако и Франция. Так, например, Монако, не может заключать международные договоры с другими государствами без предварительного согласия Франции. При этом следует обратить внимание на то, что современное международное право не признаёт протекторат, т.к. он не соответствует принципам суверенного равенства государств и права наций на самоопределение, нормам права, содержащихся в Уставе ООН, Декларации о предоставлении независимости колониальным странам и народам (1960 г.) и др.

${ }^{10}$ По условиям Версальского договора 1919 г. Германия отказалась не только от своих прав Египте и Марокко, но и признала протекторат Великобритании над территорией Египта, а Франции - над территорией Марокко. Такое правовое положение можно охарактеризовать как «мнимый суверенитет якобы государства» (протекторат Японии над территорией Маньчжурии в 1932 г., Германии над территориями Богемии и Моравии в 1939 г.). 
сов» становилась интервенционным правом. Оно нарушало принцип, предложенный немецким дипломатом и учёным Э. де Ваттелем: мирное население не должно быть объектом военных действий ${ }^{11}$. В действительности, население контролируемых и охраняемых государств, оставаясь субъектом международного права, становилось объектом политики.

Особенность правовой природы населения, как субъекта права и связывающего элемента государства, состоит в том, как полагал Г. Еллинек, что индивиды могут проявлять себя как объект государства, противодействуя ему. В некоторых областях страны (например, в колониях, на контролируемых территориях), где государственная власть требует от граждан только обязанностей, отношения изменяются по схеме: от субъекта к объекту. В таких случаях система «трёх элементов» распадается. Следствием такого распада выступают: революции, восстания, гражданские войны и вооружённые конфликты международного характера. Практика международных отношений подтвердила достоверность теоретических исследований Г. Еллинека и его последователей ${ }^{12}$.

Протекторат, эволюционируя в сторону права силы и установления отношений открытого подчинения и властвования, находил новые формы выражения. В системе международного права формируется институт кондоминиума.

Кондоминиум предполагает совместное осуществление государственного суверенитета двух и более государств на одной территории. Когда возникает вопрос о субъекте международного права, то кондоминиум следует рассматривать как объединение государств.

Эта форма ограничения суверенитета государства применялась в практике международных отношениях XIX-XX веков. Так, например, кондоминиум Пруссии и Австрии над Шлезвиг-Гольштейном и Ландебургом, существовал до 1864 г. ${ }^{13}$. После по-

${ }^{11}$ Vattel E. de. Le droit des gens ou principes de la loi naturelle. / (Deutsche überz. von W. Euler). J.C.B. Mohr (Paul Siebeck). Tübingen. Bd. III. 1959. - S.464-466.

${ }^{12}$ Как правило, результаты политики иностранного вмешательства, имеют негативные последствия. Так, например, «цивилизованные» страны, в силу невозможности колонизировать Китай, широко использовали торговлю концессиями и аренду территорий. Английский историк Н. Дэвис писал: «Европейцы так ценили китайское императорское правительство, что в 1901 г. оно стало объектом соединённого европейского протектората. Этот унизительный эпизод стал тем толчком, который через 10 лет привёл к созданию националистической Китайской республики и началу новой истории Китая. См. подр. Дэвис Н. История Европы. М., 2006. - С.629.

${ }^{13}$ Frieden von Wien zwischen Österreich und Preußen einer-, Dänemark anders vom 30. Oktober 1864. In: Strupp K. Urkunden zur Geschichte des Völkerrechts. In 2 Bände. Band I. Bis zum Berliner Kongres (1878). Vrlg. Friedrich Andreas Perthes A.G. Gotha. 1911. - S. 236-239. ражения Австрии, в так называемой, немецкой войне (1866 г.), права управления на подконтрольной территории перешли к Пруссии ${ }^{14}$.

Сервитут (от лат. servitus-обязанность, обязательство). Ограничение суверенитета государства в отношении определённого участка его территории в пользу другого государства на основе международного договора. В конце XIX - начале XX в.в. германская концепция международного права активно внедряла это понятие в международно-правовой обиход. Сервитутами называли различные способы временного пользования иностранной территорией: аренда морских портов и баз, концессии, транзитное перемещение и др. Расширительное толкование этого правового института использовалось государствами для достижения своих политических целей, а в настоящее время приняло латентный характер.

Такую форму ограничения суверенитета Китая применяла Германия в 1898 г., арендуя область Киао-Чжау, а уже в 1900 г., в нарушении условий договора, немецкий экспедиционный корпус принял участие в подавлении восстания «боксёров» в Пекине ${ }^{15}$.

Нормы права ст. 89 Версальского мирного договора устанавливали порядок использования Германией «польского коридора» в целях транзитного перемещения, а в ст. 380 этого же договора определялся правовой статус Кильского канала и порядок прохождения через него кораблей и торговых судов в мирных целях.

Расмотренные теории государственного суверенитета и формы его ограничения немецкими учеными XVII-XIX вв. были обусловлены их представлением к государству как к субъекту международного права.

Теоретическую основу для исследования государства как субъекта международного права для философов и юристов Германии составили положения естественной теории права (труды Ж. Бодена ${ }^{16}$, Т. Гоббса ${ }^{17}$, Д. Локка ${ }^{18}$,

\footnotetext{
${ }^{14}$ Geisteiner Konvention vom 14. August 1865. In 2 Bände. Band I. Bis zum Berliner Kongres (1878). Vrlg. Friedrich Andreas Perthes A.G. Gotha. 1911. - S. 240-242.

${ }^{15}$ Немецкий экспедиционный корпус под командованием графа фон Вальдзее насчитывал 20 тысяч человек личного состава. Численность группы освобождения объединённых войск, возглавляемой сэром Альфредом Гейзли, в состав которой входили армейские части России, США, Индии и Японии, также составляла 20 тысяч военнослужащих. См. подр.: Дэвис Н. История Европы. M., 2006. - С. 630.

${ }^{16}$ См.: Боден Ж. Шесть книг о республике // Антология мировой политической мысли. - М., 1991. Т. І. - С. 24-358.

${ }^{17}$ Гоббс T. Левиафан, или Материя, форма и власть государства церковного и гражданского. - М., 1936.

18 Локк Дж. Два трактата о правлении. // Локк Дж. Соч. в 3-х томах., М., 1988. Т. III.
} 


\section{Право и политика $8(164) \cdot 2013$}

Ж.Ж. Руссо ${ }^{19}$ о сущности теории общественного договора) и философско-правовые идеи Г. Гроция ${ }^{20}$.

К числу первых и наиболее законченных работ по обозначенной проблеме относится исследование Г. Гроция «О праве войны и мира» в котором автор, обратил внимание на триаду любого государства: население, территория и власть. «...власти обыкновенно подчинены двоякого рода предметы: во-первых, лица..., во-вторых, пространство, называемое территорией», - отмечал голландский учёный ${ }^{21}$.

Идеи Г. Гроция получили широкое распространение за рубежом. Исследователи, в конкретный исторический период, в зависимости от принадлежности к определённому этносу и национальной культуре, личного отношения ко внешней и внутренней политике, проводимой органами государственной власти, развивали и трансформировали правовую мысль с различных позиций. При таком подходе большинство классификаций имело дискриминационный характер, что свидетельствовало о силе государства, представитель которого обосновывал его внешнеполитическую деятельность в предлагаемой концепции.

В XIX в. представления о субъектах международного публичного права в Германии, несмотря на разногласия учёных, были выражены целостной картиной. Среди основных критериев дифференциации государств можно выделить:

- религиозный (Ф. Лист) ${ }^{22}$;

- территориально-географический (Э. де Ваттель,

И. Г.Г. Юсти и др.);

- геополитический (Ф. Цорн, М, Зейдель и др.);

- «отрицательный» (А. Меркель);

- культурологический (Р. Мооль);

- критерий силы (А.В. Гефтер, М, Зейдель, Р. Иеринг, А. Меркель, Ф. Цорн и др) ${ }^{23}$, включая их формы правления.

Достаточно стойкой по продолжительности была дифференциация государств (с различными изменениями и дополнениями) по исповедуемой народами религии $-\mathrm{Ha}$ христианские и нехристианские. Этот дискриминационный критерий просуществовал до XIX в.

Отношение к нехристианским государствам меняется после установления нового типа международного правопорядка. В истории международных отношений он получил

${ }^{19}$ Руссо Ж.Ж. Об общественном договоре или начала политического права. - М., 1906.

${ }^{20}$ Гроций Г. О праве войны и мира. Три книги. - М., 1994.

${ }^{21}$ Гроиций. Г. Указ. раб. - С.218.

22 Так, например, государства, где господствующей религией признавался ислам, длительное время были исключены из межгосударственного общения.

${ }^{23}$ См. подр.: Каширкина А.А. Представления о субъектах международного публичного права в классической доктрине XVII - XIX в.в. // Межд. публ. и частное право № 1 (10), 2003, № 1 (10). - С. 49-54. название - Венская система (1815-1918 г.г. $)^{24}$. Указанному подходу способствовали следующие причины:

а) возникновение независимых государств на американском континенте после национально-освободительных революций и принятие ими христианства;

б) признание Турции, по условиям Парижского мирного договора 1856 г., целостным и независимым государством;

в) включение в Японии и Китая в систему межгосударственного общения ${ }^{25}$.

Параллельно с религиозным признаком, широкое признание получила классификация, согласно которой государства различались по территориально-географическому признаку. Эта идея, впервые выдвинутая Г. Гроцием, нашла своё отражение в трудах немецких учёных Э. де Ваттеля и И. Г.Г. Юсти. В современном международном праве она не применяется в чистом виде, т.к. противоречит общим принципам международного права. Однако её идеологический компонент дискриминирует государства и проявляется в абсолютизации регионализма, во внешнеполитических и внешнеэкономических доктринах, преследующих цель - намеренно противодействовать интеграционным процессам в мире.

Появление на политической карте мира всё большего количества государств ${ }^{26}$, способствовало установлению между ними дипломатических отношений, и как следствие - развитию права внешних сношений. Дипломатическая практика значительно опережала теоретические идеи юристов-международников. В науке складывалась ситуация,

\footnotetext{
${ }^{24}$ В истории международных отношений выделяют следующие типы международного правопорядка: Вестфальская система (1648-1815 гг.); Венская система («Европейский концерт» 1815-1918 гг.); Версальская система (1919-1945 гг.); Ялтинская система (1945-1991 гг.). См. напр.: Антонов И.П. Основные проблемы германской концепции международного права. - М., 2007. - C. 71-84.

${ }^{25}$ Freundschaft-und Handelsvertrag zwischen China einerseits, den Staaten des Deutschen Zoll-und Handelsvereins, beiden Meklenburg, Hamburg, Lübeck, Bremen (jetz dem Deutschen Reich) anderseits vom 2. September 1861. In: Strupp K. Urkunden zur Geschichte des Völkerrechts. In 2 Bände. Band I. Gotha 1911. Vrlg. Friedrich Andreas Perthes A.G. S. 347-357. К началу работы Первой конференции мира в Гааге, которая состоялась в мае-июле 1899 г., Япония уже заключила договоры с США-1854 г., с Россией-1855 г., с Великобританией-1902 г., а Китай-с Великобританией-1842 г., с Францией- 1858 г. и Германией-1861 г

${ }^{26}$ Образование новых государств и увеличение их количества заметно расширило географическое пространство международной системы. Если на Второй «мирной конференции» в Гааге приняли участие 44 государства, то незадолго до окончания Второй мировой войны их насчитывалось до 60, а с 1945 г. до середины 80-х годов $\mathrm{XX}$ столетия количество государств в международной системе увеличилось боле, чем в два раза. Dahm G., Delbrük J., Wolfrum R. Völkerrecht. 2. Aufl, in 3 Bände - Walter de Grayter - Berlin - New York. B., 1989. B. 1/1. - S. 9; 10.
} 
DOI: $10.7256 / 1811-9018.2013 .8 .9128$

При цитировании этой статьи сноска на doi обязательна

Правовая и политическая мысль

при которой разрабатываемые учёными теории имели политическую окраску и должны были «обслуживать» внешнюю политику государств, оправдывая при этом незаконные захваты иностранных территорий. Именно по этой причине неравенство государств и законность геополитического передела мира стали основными направлениями развития научно-правовой мысли в XIX столетии.

Правовым оформлением дискриминации послужил цивилизационный (или культурологический) подход к классификации государств ${ }^{27}$. Теория градации государств на «циивилизованные» и «нециивилизованные» устраивала политиков индустриальных государств Европы и США.

Широкое распространение она получила в Германии, о чём свидетельствует анализ научной литературы ХIX-XX в.в. ${ }^{28}$.

Один из основателей учения о дуалистической природе международного права - Г. Трипель, в работе «Международное право и внутригосударственное право» (1899 г.), отмечал: «...nонятие «международное право» охватывает отношения между вышестоящими и нижестоящими государствами, илимежду равноправными» ${ }^{29}$.

Известный учёный в области уголовного права, уделявший особое внимание исследованию основам государства и проблемам международного права профессор Ф. Лист был убеждённым сторонником того, что субъектами международного права являются только цивилизованные государства ${ }^{30}$. Среди критериев циви-

\footnotetext{
${ }^{27}$ Автором идеи дифференциации государств на «цивилизованные» и «нецивилизованные» принято считать известного российского учёного, юриста-международника Ф.Ф. Мартенса. См. подр.: Мартенс Ф.Ф. Современное международное право цивилизованных народов. Т. І. Изд-е V. - СПб. 1909; Энциклопедический словарь. Т. XV А Коала-Конкордія. Изд. Ф.А. Брокгаузъ (Лейпциг), И.А. Ефрон (С-Петербургъ). С.-Пб. 1895. - С. 736. Однако, мнение по поводу того, кто же в действительности первым предложил такую классификацию государств небесспорно. Еще в 1866 г. немецкий ученый И.К. Блюнчли (Bluntschli J.) (швейцарец по происхождению) приобрел известность, опубликовав научный труд «Современное военное право цивилизованных государств» («Das modern Kriegsrecht der zivielisierten Staaten». Nördlingen. 1866), a в 1867 г. - «Современное международное право цивилизованных государств, представленное в виде кодекса» («Das moderne Völkerrecht der zivielisierten Staaten als Rechtbuch dargestellt». Nördlingen. 1867).

${ }^{28}$ См. напр.: Stier-Somlo F. Völkerrecht. In: Handwörterbuch der Rechtswissenschaft. Hrsg. Von Fritz Stier-Somlo und Alexander Elster. Walter de Gruyter und Co. Berlin und Leipzig. 1929. In 8 Bände. Band 6. - S. 672-686; Lasson A. Prinzip und Zukunf des Völkerrechts. Berlin. 1871; Zorn A. Grundzüge einer allgemeinen Staatslehre. Leipzig. 1903 u. a.

${ }^{29}$ Triepel H. Völkerrecht und Landesrecht. Leipzig. Vrlg. von C.L. Hirschfeld. 1899. - S. 20.

${ }^{30}$ List F. v. Das Völkerrecht. Systematisch dargeschtelt. 12.bearb. Aufl. Berlin. Vrlg. v. Julius Springer 1925. S.; 2; 3; 85-94. Этот научный труд пользовался широкой популярностью и ещё при жизни учё-
}

лизованных государств он выделял: культурологический, религиозный, включая господствующую форму собственности. «...полуциивилизованные государства принадлежат к международно-правовому общению только в тех своих отношениях, которые регулированы договорами с культурными государствами» ${ }^{31}$ и далее, при межгосударственном общении «с полуцивилизованными государствами вне отношений, регулированных договорами, и при всех сночениях с нецивилизованными государствами, правовое общение культурных государств охраняется только фактическим могуществом последних, и связано только с началами христианства и гуманности» ${ }^{32}$, - отмечал Ф. Лист. В отношении к таким странам как Абиссиния, Китай, Либерия, Марокко, Персия, Сиам он писал, что они являются государствами, «близкими к международно-правовому общению, но не вполне к нему принадлежащими» ${ }^{33}$.

Во второй половине XIX в. немецкая школа международного права разрабатывает новое направление в классификации государств, где страны дифференцируются на «сильные» и «слабые». Представители указанного подхода А.В. Гефтер ${ }^{34}$, А. Меркель ${ }^{35}$ и др, оправдывая военную экспансию Германии и обосновывая её участие в переделе мира, предложили для градации государств критерий силы. Интерпретируя учение Г. Гроция о праве справедливой войны, они в своих работах научно аргументировали возможность произвола и беззакония на «благо» своего государства по отношению к другим странам. Развивая теорию насилия Р. Иеринг, А. Лассон и Ф. Цорн трансформировали её в геополитическую концепцию признания государств как субъектов международного права ${ }^{36}$. Эта концепция обоснована в научном труде известного немецкого дипломата и юриста Р. Мооля «Государственное право, международное право и политика» (1860-1869). Автор отмечал, для того, чтобы международное сообщество, состоящее из цивилизованных государств, приняло решение о признании другого государства как субъекта

ного выдержал 11 изданий. См. подр.: Juristen. Ein biographisches Lexikon. Von der Antike bis zum 20. Jahrhunder. Hrsg. v. Michael Stolleis. Vrlg. C.H. Beck. München. 1995.

${ }^{31}$ Лист Ф. Международное право в систематическом изложении. Пер. с нем. - Юрьев, 1912. - С. 6.

32 Лист Ф. Указ. раб. - С. 7.

${ }^{33}$ Лист Ф. Указ. раб. - С. 8.

${ }^{34}$ Heffter A.W. Das europäische Völkerrecht der Gegenwart., 7. Aufl. Berlin. 1881.§ 2. - S. 22-26 u. flg.

${ }^{35}$ Merkel A. Recht und Macht in Schomoller's Jahrbuch's. 1881. - S. 439 u. flg.

${ }^{36}$ См. напр.:Ihering R. v. Der Kamf um's Recht. Leipzig. 1872.; Lasson A. Das Kulturideal des Kriegs. Berlin. 1871; Zukunft des Völkerrechts. Berlin 1871. B.I; Zorn F. Das Staatsrecht des Deutschen Reichs. Berlin. 1883. B. II. 


\section{Право и политика $8(164) \cdot 2013$}

международного права, оно должно иметь определённые обязанности пред сообществом и систему правоотношений на основе внутригосударственного права. Международное сообщество при этом может преследовать определённые интересы ${ }^{37}$.

Формирование подобного рода теорий в науке международного права среди немецких юристов было обусловлено особенностями внешней политики, проводимой политическим руководством и изменениями социальноэкономической ситуации в стране. Германия периода 18501860 г.г. характеризуется ростом национального сознания, связанного с началом экономической трансформации, сопровождающейся ростом городов ${ }^{38}$. За короткий срок она становится индустриальной державой. Экономическая жизнь протекает внутри Таможенного союза, освобождая страну от иностранной зависимости.

Во внутриполитической жизни государства происходят радикальные перемены. В 1862 г. премьерминистром прусского правительства назначается О. Бисмарк. В своих устремлениях к объединению немецкой нации он «железом и кровью» укрепляет международный авторитет государства. Три победоносных войны под предводительством Пруссии (в 1864 г. над Данией, в 1866 г. над Австрией и в 1871 г. над Францией), способствовали созданию Второй германской империи и принятию 16 апреля 1871 г. имперской конституции. Именно при Бисмарке в 1884 г. Германия начала колониальные захваты в Африке (современные Камерун, Намибия, Танзания, Того) и на Маршалловых островах в Тихом Океане ${ }^{39}$. Основной принцип политики «железного канцлера» был выражен в том, что: «Право является хорошо понятой политикой силь»» ${ }^{40}$.

Процесс эволюции государств сопровождался изменением их интересов и отношением к средствам производства. Если до XX в. государства считали неогра-

\footnotetext{
${ }^{37}$ Mohl R. v. Staatsrecht, Völkerrecht und Politik. In zwei Bände. Erser Band: Staatsrecht und Völkerrecht. Tübingen. 1860. Vrlg. der H. Laupp'schen Buchhandlung - Laup \& Siebeck. - S. 620, 621.

${ }^{38}$ Если к началу 1800 г. население Германии, проживающее в сельской местности составляло около $90 \%$, а в городах его численность приближалось к 5\%, то в 1871 г.уже 50\% жителей считали себя горожанами. См. подр: Schulze H. Kleine deutsche Geschichte. Verlag C.H. Beck. München. 1996. - S.136.

${ }^{39}$ См. подр.: Ebel F., Thielmann G. Rechtsgeschichte ( Von der Römischen Antike bis zur Neuzeit ) 3., neu bearb. Aufl., C.F. Müller Vrlg. - Heidelberg, 2003. - S. 308; 321-324; 345; Schulze H. Kleine deutsche Geschichte. - Verlg. C.H.Beck - München, 1996. - S.105-121; 151-155; Fichter A. Die völker-und Staatliche Stellung der deutschen Kolonialgesellschaft des 19. Jahrhunderts. Dissertation zur Erlangung des Grades eines Doktor der Rechtswissenschaft des Fachbereiches Rechtswissenschaf der Universität Hamburg. 2002. Дроз Ж. История Германии -М., 2005. - С. 45-68; Павлов Н.П. Современная Германия.-М., 2005. - С. 485-490.

${ }^{40}$ Дроз Ж. История Германии -М., 2005. - С.59.
}

ниченным своё право на ведение войны с целью захвата новых территорий и их колонизацию для обеспечения себя дополнительными ресурсами посредством эксплуатации, то к началу XX в., с установлением Версальской системы (1919-1945 г.г.), научно-правовые идеи о сущности государства подвергаются кардинальным изменениям. В исследованиях учёных получает развитие новое направление - классификация по формационному признаку, при которой различают рабовладельческие, феодальные, капиталистические и социалистические государства.

Вышеизложенный анализ представлений о государствах как основных субъектах международного публичного права, позволяет выявить два характерных признака, свойственным немецким концепциям периода XVII-XIX в.в.:

1. Учение о неравенстве государств.

2. Возможность геополитического передела мира легитимным способом, т.е. - право на войну.

Более детальное исследование положений этих концепций приводит нас к следующим выводам:

- выбор критериев, дискриминирующих государства и определяющих их включение или не включение в круг международного общения, был естественным и закономерным явлением для немецкой концепции международного в период XVII-XIX в.в.;

- дифференциация государств по исповедуемой населением религии, свидетельствует о низком уровне демократизации международного права рассматриваемого периода, в то время как культурологический критерий опровергает несостоятельность такой классификации;

- обоснование внешней политики государства, с возможностью проведения колониальных захватов, способствовало формированию геополитических концепций в научных кругах Германии;

- легитимность войны (критерий силы) как один способов разрешения международных столкновений был нежелательным, но допустимым в международном праве до ХХ в.;

- расширение круга международного общения, субъекты которого устанавливают свои отношения на общих принципах международного права, создали предпосылки для прогрессивных идей и подходов к государству как основному субъекту международного публичного права.

При современных подходах к государству как одному из основных субъектов международного публичного права учёные ФРГ, руководствуясь основополагающими идеями Г. Еллинека о трёх элементах государства ${ }^{41}$, рассматривают его как совокупность территории, населения и государственной власти. Особенность их научно-теоретических взглядов состоит в следующем:

${ }^{41}$ Jellinek G. Allgemeine Staatslehre. Vrlg. von O. Häring. Berlin. 1900. - S. 293-355. 
DOI: $10.7256 / 1811-9018.2013 .8 .9128$

При цитировании этой статьи сноска на dоі обязательна

Правовая и политическая мысль

a) государственная территория - это не только географическое пространство в пределах государственных границ (наземных, воздушных и водных), а прежде всего пространственная сфера действия установленного правопорядка (например, Дания и о. Гренландия, Франция и Мартиника, Великобритания и Фолклендские острова) ${ }^{42}$;

б) население государства представляет собой союз людей, различных групп, находящихся под суверенитетом государства (территориальным и личным), взаимосвязанных не языком, культурой, расой, историей или религией, а объединением, подчинённым единому правопорядку (например, граждане государств-членов ЕС) 43; $^{43}$

в) государственная власть является цементирующим звеном между территорией и населением государства. Именно она обладает юридическим свойством организовывать конституционный порядок в пределах своей территории (внутренний суверенитет) и обеспечивать независимость в международных отношениях (внешний суверенитет) $)^{44}$.

Таким образом, теория о трёх элементах государства и теория признания государств соотносятся между собой через содержание научного понятия «суверенитет».

Относительно теории суверенитета государства, то следует заметить, что суверенитет как один из признаков государства, изменчив по форме, поскольку связан с правоспособностью государства ${ }^{45}$. Но поскольку, согласно общей теории права, можно разделить лишь права, а не правоспособность, очевидной становится идея неделимости суверенитета.

${ }^{42}$ Ipsen K. Völkerrecht. 5., v. neubearb. Aufl., Vrlg. C.H. Beck. München, 2004. - S. 60.

${ }^{43}$ Ipsen K. Op. cit. - S. 61; Vertrag über die Europäische Union. 01. 11. 1993. Art. 1 In: Verträge der Bundes Republik Deutschland. Serie: Multilaterale Verträge. Nr. 900-908. Band 73. Hrsg. von Auswärtigen Amt. Carl Heymanns Vrlg. KG Bonn. Köln. Berlin. 1995. - S. 334-517.

${ }^{44}$ Аналогичный подход к государству отражён в практике международных отношений. Так, например, нормы международного права ст. 1 «Межамериканской конвенции о правах и обязанностях государств» от 26.12.1933 г. определяют, что «Государство, как субъект международного права должно обладать следующими признаками: а) постоянным населением; б) определённой территорией; в) правительством; г) способностью вступать в сношения с другими государствами».

В заявлениях министерства иностранных дел США (1974 г.) и Федерального правительства ФРГ (1975 г.) о признании государства - Республика Гвинея-Биссау, содержалась ссылка именно на эту статью Конвенции Монтевидео (Montevideo Konvention), названной по месту её заключения. Аргумент подобного рода был также использован при подписании директивы ЕС «О признании новых государств в Восточной Европе и в Советском Союзе» (Брюссель, 16.12.1993 г.).

${ }^{45}$ В этой связи трудно согласиться с мнением профессора Моисеева А.А., который полагает, что суверенитет -это «это неотчуждаемое качество независимого государства ...». См. подр.: Моисеев А.А. Суверенитет государства в международном праве. Учебн. пособие. - М., 2009. - С. 68.
В зависимости от целей государства при осуществлении внутренней и внешней политики, происходит изменение видов суверенитета, сам же он остаётся неотъемлемым признаком государства. В практике международных отношений дисбаланс между его юридической и политической составляющими нередко зависит от внутренних факторов (нарушения прав человека и последствия, связанные с ними) и внешних воздействий других субъектов международного права (интервенция, оккупация, протекторат и др.).

\section{Библиография:}

1. Акт относительно признания и гарантии постоянного нейтралитета Швейцарии и неприкосновенности её территории, от 8 (20) ноября 1815 г. / Действующее международное право. В трёх томах. Составители проф. Ю.М. Колосов и проф. Э.С. Кривчикова. - М.: Издательство Московского независимого института международного права, 1996. T. I. C. 141-142;

2. Аннерс Э. История европейского права. - М.: Инст-т Европы. «Наука», 1999. - 395 с.;

3. Бержель Ж.-Л. Общая теория права. Пер. с франц. Г.В. Чуршукова / Под общ. ред. проф. В. И. Даниленко. — M.: Nota Bene, 2000. — 576 c.;

4. Берман Дж. Западная традиция права: эпоха формирования. - М.: Изд-во Московского университета, 1994. - 592 с.;

5. Гулыга А.В. Немецкая классическая философия. 2-е изд., испр. и доп. - М.: «Рольф», 2001. — 416 с. ;

6. Гулыга А.В. Кант. - 4-е изд., испр. и доп. - М.: «Молодая гвардия», 2005. - 280 с.;

7. Кокошин А.А. Реальный суверенитет. - М.: «Европа», 2006. - 88 с.

8. Мартенс Ф.Ф. Современное международное право цивилизованных народов. Т. І. Изд-е V.-СПб., 1909.438 c.;

9. Нерсесянц В.С. Философия права Гегеля. - М.: Юристь, 1998. - 352 с.;

10. Патрушев А. Германская история. - М.: Изд-во «Весь мир», 2003. - 256 с.;

11. Феллер В.В. Германская одиссея. - Самара.: Самар. Дом печати, 2001. - 344 с.;

12. Дэвис Н. История Европы. М., 2006.-С. 630;

13. Гроций Г. О праве войны и мира. Три книги.-М., 1994;

14. Шпенглер О. Закат Европы. Очерки мировой истории. В 2-х томах / Пер. с нем. К.А.Свасьяна. - М.: «Мысль», 1998. Т. І. Гештальт и действительность. $-663 \mathrm{c}$;

15. Anzilotti D. Lehrbuch des Völkerrechts. Bd. 1., Verlag Berlin, Leipzig. 1929. — 487 S.; 
DOI: $10.7256 / 1811-9018.2013 .8 .9128$

При цитировании этой статьи сноска на dоі обязательна

\section{Право и политика $8(164) \cdot 2013$}

16. Geiger R. Grundgesetz und Völkerrecht. 2. Aufl. Verlag C.H. Beck. München. 2002. — 422 S.;

17. Doehring K. Völkerrecht. C.F. Müller Verlag. Heidelberg. 2004. - 556 S.;

18. Grewe W. G. Epochen der Völkerrechtsgeschichte. Nomos Verlaggesellschaft. Baden-Baden. 1988. $897 \mathrm{~S}$;

19. Ziegler K. H. Völkerrechtsgeschichte. Verlag. C.H. Beck. München. 1994. - $320 \mathrm{~S}$.

\section{References (transliteration):}

1. Anners E. Istoriya evropeyskogo prava. - M.: Inst-t Evropy. «Nauka», 1999. - 395 s.;

2. Berzhel' Zh.-L. Obschaya teoriya prava. Per. s franc. G.V. Churshukova / Pod obsch. red. prof. V. I. Danilenko. M.: Nota Bene, 2000. — 576 s.;

3. Berman Dzh. Zapadnaya tradiciya prava: epoha formirovaniya. - M.: Izd-vo Moskovskogo universiteta, 1994. - 592 s.;

4. Gulyga A.V. Nemeckaya klassicheskaya filosofiya. 2-e izd., ispr. i dop. — M.: «Rol'f», 2001. — 416 s. ;

5. Gulyga A.V. Kant. - 4-e izd., ispr. i dop. - M.: «Molodaya gvardiya», 2005. — 280 s.;
6. Kokoshin A.A. Real'nyy suverenitet. - M.: «Evropa», 2006. - $88 \mathrm{~s}$.

7. Martens F.F. Sovremennoe mezhdunarodnoe pravo civilizovannyh narodov. T. I. Izd-e V.-SPb., 1909.-438 s.;

8. Nersesyanc V.S. Filosofiya prava Gegelya. - M.: Yurist', 1998. - 352 s.;

9. Patrushev A. Germanskaya istoriya. - M.: Izd-vo «Ves’ mir», 2003. - $256 \mathrm{~s}$;

10. Feller V.V. Germanskaya odisseya. - Samara.: Samar. Dom pechati, 2001. - 344 s.;

11. Devis N. Istoriya Evropy. M., 2006.-S. 630;

12. Grociy G. O prave voyny i mira. Tri knigi.-M., 1994;

13. Shpengler O. Zakat Evropy. Ocherki mirovoy istorii. V 2-h tomah / Per. s nem. K.A.Svas'yana. - M.: «Mysl'», 1998. T. I. Geshtal't i deystvitel'nost'. — 663 s.;

14. Anzilotti D. Lehrbuch des Völkerrechts. Bd. 1., Verlag Berlin, Leipzig. 1929. — 487 S.;

15. Geiger R. Grundgesetz und Völkerrecht. 2. Aufl. Verlag C.H. Beck. München. 2002. — 422 S.;

16. Doehring K. Völkerrecht. C.F. Müller Verlag. Heidelberg. 2004. - 556 S.;

17. Grewe W. G. Epochen der Völkerrechtsgeschichte. Nomos Verlaggesellschaft. Baden-Baden. 1988. — 897 S.;

18. Ziegler K. H. Völkerrechtsgeschichte. Verlag. C.H. Beck. München. 1994. - 320 S. 